https://doi.org/10.17816/MAJ191S1100-101

\title{
ENDURANCE OF RATS WITH DISBIOZ IN EMOTIONAL-PHYSICAL STRESS
}

\author{
A.F. Safonova, I.B. Krylova, K.A. Shemerovsky \\ Institute of Experimental Medicine, Saint Petersburg, Russia

\section{ВЫНОСЛИВОСТЬ КРЫС С ДИСБИОЗОМ ПРИ ЭМОЦИОНАЛЬНО-ФИЗИЧЕСКИХ НАГРУЗКАХ}

\author{
А.Ф. Сафонова, И.Б. Крылова, К.А. Шемеровский \\ ФГБНУ «Институт экспериментальной медицины», Санкт-Петербург
}

\begin{abstract}
Stress loads in sport lead to the development of functional disorders of various body systems, including the digestive system. The use of pharmacological preparations for correction of dysbiotic states is very often. The aim of this work was to study the physical endurance of rats with dysbiosis with decreased and increased intestinal circadian rhythm (ICR) under conditions of emotional-physical stress. Dysbiosis with a decreased ICR was caused by the administration of loperamide (LPR) $2 \mathrm{mg} / 2 \mathrm{ml}$ of physiological saline daily subcutaneously for 6 days. Dysbiosis with increased ICR was caused by the addition of lactitol (LT) $10 \mathrm{~g}$ to $200 \mathrm{ml}$ of drinking water daily for 6 days. To model emotional-physical stress, a forced swimming test until exhaustion (drowning) with a load of $7 \%$ of the animal's body weight and a water temperature of $14{ }^{\circ} \mathrm{C}$ was used. In the control group, the life span of rats was $136 \pm 8 \mathrm{~s}$. LPR increased the physical endurance of rats by 1.94 times compared with control. LT also had a positive effect, increasing the duration of forced swimming in 1.44 times compared with the control. The combined use of LPR and LT did not lead to a change in animal's endurance. Thus, both types of dysbiosis can be considered as a variant of endogenous stress, which plays the role of adaptogenic factor that increases resistance to a stronger emotional-physical stress, leading to the increase in physical endurance of animals.
\end{abstract}

Keywords: stress; dysbiosis; loperamide; forced swimming; physical endurance.

Стрессовые нагрузки у спортсменов приводят к развитию функциональных нарушений различных систем организма, в том числе пищеварительной. Во время интенсивных тренировок и спортивных соревнований рекомендуется принимать фармакологические препараты, вызывающие коррекцию дисбиотических состояний, часто возникающих у спортсменов. Целью данной работы явилось изучение физической выносливости мелких лабораторных животных при дисбиозе с урежением и учащением циркадианного ритма кишечника (ЦРК) в условиях эмоционально-физического стресса. Дисбиоз с урежением ЦРК у крыс вызывали введением лоперамида (ЛПР) 2 мг/2 мл физиологического раствора ежедневно подкожно в течение шести суток. Дисбиоз с учащением ЦРК вызывали добавлением лактитола (ЛТ) в воду для питья из расчета 10 г на 200 мл воды ежедневно в течение 6-ти суток. Для моделирования эмоционально-физического стресса использовали тест принудительного плавания с нагрузкой $7 \%$ от массы тела животного и температурой воды $14{ }^{\circ} \mathrm{C}$ до полного изнурения (утопления). В контрольной группе животных продолжительность жизни крыс составила $136 \pm 8$ сек. ЛПР увеличивал физиологическую выносливость крыс в 1,94 раза по сравнению с контролем. ЛТ также оказывал положительное действие, увеличивая продолжительность принудительного плавания в 1,44 раза по сравнению с контролем. Совместное применение ЛПР и ЛТ не привело к изменению выносливости животных. Таким образом, дисбиоз обоих типов можно рассматривать как вариант эндогенного стресса, который выполняет роль адаптогенного фактора, повышающего устойчивость к более сильному эмоционально-физическому стрессорному воздействию, в результате чего наблюдается увеличение физической выносливости животных.

Ключевые слова: стресс; принудительное плавание; дисбиоз; лоперамид; физическая выносливость.

Introduction. Stress loads in sport lead to the development of functional disorders of various body systems, including the digestive system. The use of pharmacological preparations for correction of dysbiotic states is very often. The aim of this work was to study physical endurance (PhE) of rats with dysbiosis on the model of emotional-physical stress caused by forced swimming with load.
Material and methods. 22 Wistar male rats with the initial weight of 250-280 g were used. Dysbiosis with decreased intestinal circadian rhythm (ICR) was caused by administration of loperamide (LPR) according to Han S.H. et al. [5] in our own modification. $2 \mathrm{mg}$ of loperamide were dissolved in $2 \mathrm{ml}$ of saline and injected subcutaneously daily for 6 days. Dysbiosis with the increased 


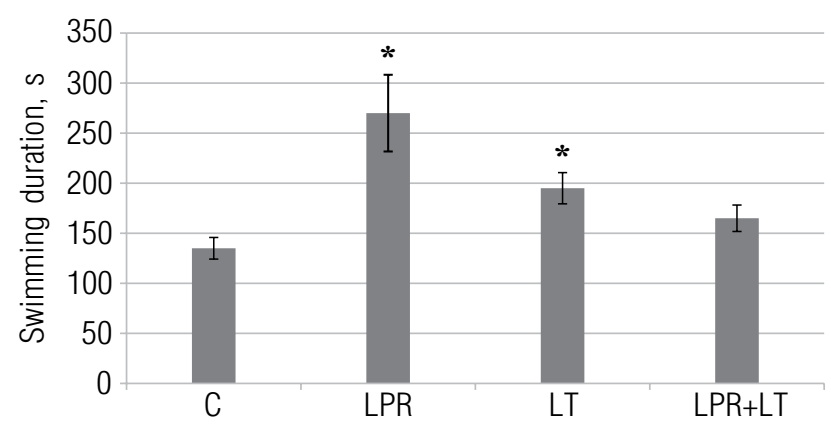

Fig. The swimming duration (s) of the rats with increased and decreased intestinal circadian rhythm in the test of forced swimming with the load. C-control, LPR loperamide, induces the decrease of intestinal circadian rhythm, LT - lactitol, induces the increase of intestinal circadian rhythm. ${ }^{*} p<0.05$, comparing with control

ICR was caused by lactitol (LT) $10 \mathrm{~g}$ added to $200 \mathrm{ml}$ drinking water daily within 6 days. 4 groups of rats were tested. $1^{\text {st }}$ group (control - C) got subcutaneous injection of $2 \mathrm{ml}$ of saline for 6 days, the $2^{\text {nd }}$ group was given LPR, the $3^{\text {rd }}-\mathrm{LT}$, the $4^{\text {th }}-$ LPR+LT. On the 7 th day all animals were subjected to emotional-physical stress - forced swimming with load $7 \%$ of body weight [1] in the water $14^{\circ} \mathrm{C}$ up to a full exhaustion (drowning) [2]. Statistical analysis was performed using Statistical GraphPad Prism 6 program.
Results and discussion. The $\mathrm{PhE}$ of the rats in control group in the test of forced swimming with load in cold water differed from the animals given LPR and LT. In LPR group (decreased ICR) PhE was higher, than in C, LT and LPR+LT groups by $1.94 ; 1.34$ and 1.68 times respectively (figure).

In LT group (increased ICR) $\mathrm{PhE}$ was higher, than in $\mathrm{C}$ and LPR+LT groups by 1.44 and 1.25 times respectively. In LPR+LT group no significant differences of $\mathrm{PhE}$ were registered in comparison with $\mathrm{C}$.

Conclusion. Thus, dysbiosis both with decreased and increased ICR resulted in the increase of $\mathrm{PhE}$ of rats under conditions of emotional-physical stress. The most positive effect was observed in dysbiosis with decreased ICR. The reaction to stress is largely determined by the properties of the stress-limiting systems of the organism. Important role belongs to opioid system. Recent data showed that LPR which we used to simulate dysbiosis with a decrease ICR is the agonist of $\mu$-opioid receptors [4]. It has an anxiolytic effect without sedation and decrease of PhE. At the same time, dysbiosis of both types can be regarded as endogenous stress [3] which plays the role of the adaptogen factor increasing resistance to stronger emotional-physical stress influence, thus increasing $\mathrm{PhE}$ of the animals. The mechanism of positive interaction of endogenous and exogenous stress requires further study.

\section{Rreferences}

1. Karkishchenko VN, Kapanadze GD, Dengina SE, Stankova NV. Development of a technique of assessment of physical endurance of small laboratory animals for studying the adaptogen activity of some drugs. Biomedicine. 2011;(1):72-74.

2. Safonova AF, Ermolenko EI, Kotyleva MP, Karaseva AB. Influence of some probiotics on endurance of rats in experimental dysbiosis. Reviews on Clinical Pharmacology and Drug Therapy. 2015;13(Special issue): 149 .

3. Shemerovsky KA. Pharmacological correction of bradyenteria as endogenous stress. Reviews on Clinical Pharmacology and Drug Therapy. 2015;13(Special issue):198.

4. Sudakov SK, Bashkatova VG, Kolpakov AA, Trigub MM. Peripheral administration of loperamide and methylnaloxonum suppresses anxietyin rats. Bull Exp Biol Med. 2010;149(3):244-246.

5. Han SH, Park K, Kim EY, Suh HJ. Cactus (Opuntia humifusa) water extract ameliorates loperamideinduced constipation in rats. BMC Complement Altern Med. 2017;17(1):49. 